\title{
PENENTUAN KADAR TANIN DALAM PELARUT ETANOL 50\% DARI KULIT BUAH MANGGIS (Garcinia mangostana L.) DENGAN BANTUAN SELULASE Trichoderma asperellum LBKURCC1
}

\author{
Miranti, Titania Tjandrawati Nugroho, Hilwan Yuda Teruna
}

\author{
Laboratorium Riset Enzim, Fermentasi dan Biomolekuler, Jurusan Kimia, FMIPA, \\ Universitas Riau Jln. Raya Bangkinang KM 12,5 Pekanbaru 28193 \\ Penulis korespondensi. E-mail: miranti@grad.unri.ac.id
}

\begin{abstract}
ABSTRAK
Tanin merupakan senyawa turunan polifenol yang memiliki berat molekul 500-3000 yang memiliki gugus hidroksi fenolik. Tanin yang terkandung dalam kulit buah manggis (Garcinia mangostana L.) dapat dimanfaatkan sebagai bahan aditif pada bahan industri cat, tekstil dan penyamak kulit. Penggunaan enzim selulase dalam proses ekstraksi tanin menggunakan alkohol 50\% diharapkan mampu meningkatkan ekstrak kadar tanin. Kulit buah manggis diekstraksi dengan dan tanpa enzim selulase Trichoderma asperellum LBKURCC1 menggunakan pelarut bufer Naasetat $0,05 \mathrm{M} \mathrm{pH} 5,5$ dan bufer-etanol dengan konsentrasi etanol 50\%. Kandungan total tanin dianalisis menggunakan metoda Folin-Denis. Hasil penelitian menunjukkan kandungan tanin per gram kulit buah manggis meningkat secara signifikan $(p<0,05)$ dengan penambahan etanol 50\% dibandingkan tanpa etanol. Sedangkan kandungan tanin per gram kulit buah manggis dengan perlakuan tanpa dan menggunakan enzim selulase tidak memberikan perbedaan hasil yang nyata $(p \geq 0,05)$.
\end{abstract}

Kata kunci: kulit buah manggis, tanin, selulase

\section{PENDAhULUAN}

Indonesia termasuk negara tropis yang mendominasi pasaran manggis di dunia bersama Thailand dan Malaysia. Manggis (Garcinia mangostana Linn.) adalah tanaman tropis dalam family Guttiferae. Kulit buah manggis telah digunakan sebagai agen pewarna, obat tradisional, antidiare, dan antidisentri. Manggis mengandung beberapa kelompok senyawa fenolik seperti tanin, flavonoid, dan xanton (Ho et al., 2002; Moongkarndi et al., 2004; Jung et al., 2006; Weecharangsan et al., 2006; Pothitirat et al., 2010).

Studi aktivitas biologis telah menunjukkan bahwa manggis dapat berfungsi sebagai antiinflamasi, antikanker, antimikroba, dan sifat antioksidan (Chomnawang et al., 2005). Ekstrak buah manggis dikonsumsi sebagai suplemen makanan karena memiliki aktivitas antioksidan, sementara ekstrak dari buah kulit manggis memiliki sifat antibakteri, yang telah direkomendasikan untuk pengobatan acne vulgaris (Kumar et al., 2008). Aktivitas biologis dari kulit buah manggis didasarkan pada kandungan senyawa yang ada didalamnya yaitu $\alpha$-mangostin, tanin, dan senyawa fenolik lainnya (Pothitirat et al., 2010).
Kulit buah manggis mengandung selulosa yang dapat dihidrolisis menggunakan enzim selulase. Teknik ektraksi senyawa tanin dari limbah tanaman dapat dilakukan menggunakan enzim untuk membantu degradasi dinding sel tanaman, sehingga senyawa yang ingin diekstraksi lebih mudah dijangkau cairan pengekstrak. Selulosa dapat dihidrolisis oleh selulase menjadi monomer-monomernya. Hidrolisis selulosa menjadi monomermonomernya diharapkan dapat meningkatkan ekstraksi senyawa tanin.

Penelitian ini dilakukan untuk menguji kemampuan enzim selulase meningkatkan ekstraksi senyawa tanin yang terkandung dalam kulit buah manggis menggunakan etanol $50 \%$. Enzim selulase yang digunakan adalah selulase yang diproduksi Trichoderma asperellum LBKURCC1.

\section{METODOLOGI PENELITIAN}

Bahan hidup: Isolat jamur Trichoderma asperellum LBKURCC1 yang merupakan koleksi laboratorium Biokimia, FMIPA, Universitas Riau, yang telah diisolasi dari tanah hutan gambut biosfer Giam Siak Kecil Bukit 
Batu, Riau dan dipelihara pada media Potato Dextroxe Agar dari penelitian terdahulu.

\section{a. Peremajaan isolat jamur Trichoderma} asperellum LBKURCC1 pada media PDA

Isolat jamur Trichoderma asperellum LBKURCC1 diambil dengan menggunakan ose secara aseptis dan diinokulasikan ke media PDA. Media PDA yang telah diinokulasikan isolat jamur Trichoderma asperellum LBKURCC1 diinkubasi pada suhu ruang selama 5 hari atau hingga spora hijau tumbuh subur.

\section{b. Inokulasi jamur Trichoderma asperellum LBKURCC1 pada media cair}

Spora jamur Trichoderma asperellum LBKURCC1 yang diremajakan pada media PDA dibilas dengan larutan salin steril $(\mathrm{NaCl}$ $0,8 \%$ ) dan dilepaskan dari media dengan menggunakan ose secara aseptis. Larutan disaring menggunakan glasswoll sehingga diperoleh suspensi spora. Sebagian suspensi spora diukur ODnya menggunakan spektrofotometer pada panjang gelombang 660 $\mathrm{nm}\left(\mathrm{OD} 660 \mathrm{~nm}=0,34 \sim 7 \times 10^{12}\right)$. Suspensi spora diinokulasikan pada media cair produksi selulase dan diinkubasi pada suhu ruang dengan pengadukan menggunakan rotary shaker pada kecepatan putaran 150 rpm selama 72 jam.

\section{c. Produksi enzim selulase}

Produksi selulase dilakukan dengan menginokulasi $1,5 \times 10^{15}$ spora dari isolat pada $300 \mathrm{~mL}$ media produksi cair selulase. Kultur cair ini kemudian diinkubasi pada suhu ruang dengan kecepatan pengocokan $150 \mathrm{rpm}$ selama 72 jam. Selulase yang telah diproduksi dalam media produksi dipisahkan dari miselia jamur menggunakan sentrifugasi dalam keadaan dingin pada suhu $5-10^{\circ} \mathrm{C}$ dan kecepatan putaran 9500 rpm selama 10 menit. Filtrat disaring menggunakan kertas Whatman GF/C sehingga diperoleh ekstrak kasar enzim. Ekstrak kasar enzim ditambahkan NaN3 hingga konsentrasi $0,02 \%$ dan disimpan dalam lemari pendingin.

\section{d. Pemekatan enzim selulase}

Enzim diendapkan dari ekstrak kasar dengan penambahan padatan $\left(\mathrm{NH}_{4}\right)_{2} \mathrm{SO}_{4}$ anhidrat secara perlahan dalam keadaan dingin $\left(5^{\circ} \mathrm{C}-10^{\circ} \mathrm{C}\right)$ sambil distirer hingga mencapai tingkat kejenuhan $80 \%$. Larutan dibiarkan selama 30 menit sambil distirer dalam keadaan dingin. Endapan disentrifugasi dingin selama 10 menit.

Endapan yang diperoleh dimasukkan ke dalam tabung mikro dan disentrifugasi menggunakan mikrosentrifuga dengan kecepatan 13.000 rpm selama 5 menit. Filtrat dibuang. Endapan ditambahkan dengan larutan buffer $\mathrm{Na}-$ asetat $0,05 \mathrm{M} \mathrm{pH}$ 5,5 hingga terjadi pemekatan yang diperkirakan mencapai $140 \times$ volume semula. Jadi misalnya volume awal adalah 140 $\mathrm{mL}$, penambahan buffer pada endapan adalah 1 $\mathrm{mL}$. Enzim pekat yang diperoleh, dihilangkan garamnya dengan mikrofiltrasi menggunakan membran ultrafiltrasi corning Spin-X ${ }^{\circledR}$ UF6 10 kDa MWCO (Cat.No.CLS431483-25EA).

\section{e. Penentuan aktivitas enzim selulase}

Analisis aktivitas enzim selulase dilakukan menggunakan substrat Carboxymethyl cellulose (CMC). Aktivitas enzim diuji sebelum dan setelah proses pemekatan. Sebanyak $500 \mu \mathrm{L}$ substrat CMC $2 \%$ dalam bufer $\mathrm{Na}$-asetat $0,05 \mathrm{M}$ pH 5,5 diinkubasi selama 5 menit dalam waterbath suhu $40^{\circ} \mathrm{C}$. Kedalam larutan substrat ditambahkan $500 \mu \mathrm{L}$ larutan enzim dalam bufer 0,05M Na-asetat dan $\mathrm{pH} 5,5$, dan diinkubasi selama 30 menit dalam waterbath suhu $40^{\circ} \mathrm{C}$. Aktivitas enzim dihentikan dengan penambahan $1 \mathrm{~mL}$ reagen Nelson-Somogyi. Tabung berisi larutan ini dipanaskan dalam penangas air selama 20 menit. Setelah larutan didinginkan hingga suhu kamar, ke dalam larutan ditambahkan $1 \mathrm{~mL}$ reagen arsenomolibdat, dihomogenkan, dan didiamkan selama 5 menit. Kedalam larutan ditambahkan $7 \mathrm{~mL}$ akuades, dihomogenkan, dan didiamkan selama 30 menit. Absorbansi diukur pada $\lambda=540 \mathrm{~nm}$.

Sebagai kontrol, tabung diisi dengan $0,5 \mathrm{~mL}$ larutan selulase dalam bufer $\mathrm{Na}$-asetat $0,05 \mathrm{M}$ pH 5,5 dan diinkubasi selama 30 menit. Setelah 30 menit sebanyak $1 \mathrm{~mL}$ larutan reagen NelsonSomogyi ditambahkan ke dalam tabung kontrol, 
vortex dan ditambahkan $0,5 \mathrm{~mL}$ larutan substrat $2 \% \mathrm{CMC}$ dalam bufer $\mathrm{Na}$-asetat $0,05 \mathrm{M} \mathrm{pH}$ 5,5. Tabung kontrol kemudian dipanaskan dalam penangas air selama 20 menit dan didinginkan hingga suhu kamar. $1 \mathrm{~mL}$ reagen arsenomolibdat ditambahkan pada tabung blanko, diamkan selama 5 menit. Setelah 5 menit, tambahkan 7 $\mathrm{mL}$ akuades, vortex hingga tercampur sempurna lalu didiamkan selama 30 menit. Pengukuran absorbansi dilakukan menggunakan spektrofotometer pada panjang gelombang 540 $\mathrm{nm}$ dan dilakukan dua kali pengulangan untuk analisis. Satu unit aktivitas enzim selulase didefinisikan sebagai banyaknya enzim yang melepaskan $1 \mu \mathrm{mol}$ gula pereduksi per-menit. Kadar protein ditentukan dengan metode Lowry (Boyer, 1993).

\section{f. Persiapan kulit buah manggis bubuk}

Kulit dipisahkan dari daging buahnya dan dipotong kecil-kecil. Kulit manggis dikeringkan menggunakan oven suhu $50^{\circ} \mathrm{C}$ selama 72 jam. Kulit manggis yang sudah kering kemudian dihaluskan menggunakan blender dan diayak menggunakan ayakan berukuran 200 mesh. Bubuk kulit manggis disimpan dalam plastik yang kedap udara.

\section{g. Persiapan ekstrak sampel}

Ekstrak dipersiapkan untuk penentuan kadar tanin. Sebanyak 2,5 gram bubuk kulit buah manggis dimasukkan ke dalam $25 \mathrm{~mL}$ etanol $50 \%$ (dalam bufer Na-asetat $0,05 \mathrm{M} \mathrm{pH} \mathrm{5,5)}$ tanpa dan dengan enzim selulase. Enzim selulase yang ditambahkan adalah sedemikian rupa sehingga konsentrasi akhir selulase dalam larutan pengekstrak menjadi $0,13 \mathrm{U} / \mathrm{mL}$. Sebagai kontrol dilakukan perlakuan yang sama tetapi hanya menggunakan bufer Na-asetat $0,05 \mathrm{M} \mathrm{pH}$ 5,5 tanpa etanol. Larutan tersebut kemudian diinkubasi selama 8 hari dalam shaking incubator pada suhu $40^{\circ} \mathrm{C}$ dengan kecepatan 100 rpm. Ekstrak sampel disaring menggunakan kertas saring biasa. Filtrat dimasukkan kedalam labu uap untuk di vacum rotary evaporator $50^{\circ} \mathrm{C}$ hingga didapat ekstrak kulit manggis. Pengeringan dilanjutkan menggunakan oven pada suhu $50^{\circ} \mathrm{C}$ dan ditimbang setiap 30 menit hingga konstan. Ekstrak yang didapat selanjutnya dianalisis kadar taninnya. Semua perlakuan diulang sebanyak tiga kali.

\section{h. Penentuan tanin}

Total tanin diukur dengan metode Saxena et al., (2013). Sebanyak 0,1 mL ekstrak kulit buah manggis dimasukkan ke dalam labu ukur yang mengandung $7,5 \mathrm{~mL}$ air, lalu ditambahkan 0,5 $\mathrm{mL}$ Folin-Denis dan $1 \mathrm{~mL} \quad \mathrm{Na}_{2} \mathrm{CO}_{3} \quad 0,5 \%$. Larutan diaduk dan dibiarkan selama 30 menit dan absorbansinya diukur pada panjang gelombang $760 \mathrm{~nm}$. Standar yang digunakan yaitu standar asam tanin.

\section{HASIL DAN PEMBAHASAN}

Ekstrak kulit manggis diekstraksi dengan 4 perlakuan menggunakan pelarut bufer $\mathrm{Na}$-asetat $0,05 \mathrm{M}$ pH 5,5 dan pelarut etanol 50\% dalam bufer Na-asetat $0,05 \mathrm{M}$ pH 5,5 dengan atau tanpa menggunakan proses enzimatis. Pelarut etanol dipilih karena merupakan pelarut organik yang memiliki kepolaran yang sama dengan senyawa tanin. Proses enzimatis pada ekstraksi senyawa tanin dari kulit buah manggis bertujuan untuk menghidrolisis selulosa dan hemiselulosa yang terdapat pada dinding sel kulit buah manggis. Sehingga diharapkan, senyawa tanin dapat terekstraksi lebih banyak karena selulosa dan hemiselulosa yang melingkupi dinding sel tumbuhan telah terdegradasi membentuk molekul yang lebih sederhana. Berdasarkan beberapa penelitian yang telah dilakukan menunjukkan bahwa kandungan senyawa polifenol meningkat ketika diberi perlakuan enzimatik selama ekstraksi (Gomez-Garcia et al., 2012). Hal ini dapat membuktikan bahwa ekstraksi menggunakan enzim merupakan teknik yang sangat efektif untuk meningkatkan hasil ekstraksi fenol dari limbah industri pertanian. Ekstraksi menggunakan enzim merupakan alternatif menarik untuk ekstraksi senyawa bioaktif dari kulit buah manggis. Tabel 1. menunjukkan hasil berat kering ekstrak dari kulit buah manggis dengan empat perlakuan ekstraksi. 
Tabel 1. Berat sampel kulit buah manggis

\begin{tabular}{cc}
\hline Perlakuan & Rerata berat ekstrak kering $(\mathbf{g})$ \\
\hline P1 & $0,0364 \pm 0,001^{\mathrm{d}}$ \\
P2 & $0,0871 \pm 0,0004^{\mathrm{c}}$ \\
P3 & $0,4796 \pm 0,011^{\mathrm{b}}$ \\
P4 & $0,6193 \pm 0,096^{\mathrm{a}}$
\end{tabular}

$\mathrm{P} 1=$ Ekstrak dalam bufer Na-asetat $0,05 \mathrm{M} \mathrm{pH} 5,5$

$\mathrm{P} 2=$ Ekstrak dalam bufer $\mathrm{Na}$-asetat $0,05 \mathrm{M} \mathrm{pH} 5,5$ dan selulase

P3=Ekstrak dalam etanol 50\%-bufer Na-asetat $0,05 \mathrm{M} \mathrm{pH} 5,5$

$\mathrm{P} 4=$ Ekstrak dalam etanol $50 \%$-bufer Na-asetat $0,05 \mathrm{M} \mathrm{pH} 5,5$ dan selulase
Harga rata-rata dengan pangkat huruf yang berbeda adalah berbeda secara nyata pada tingkat $5 \%(\mathrm{P}<0,05)$ berdasarkan uji Duncan jarak berganda.

Hasil analisis kadar tanin pada ekstrak kulit buah manggis dengan empat perlakuan dinyatakan sebagai Asam Tanin Ekuivalen (ATE) dapat dilihat pada Tabel 2.

Tabel 2. Hasil analisis kandungan total tanin ekstrak kulit buah manggis

\begin{tabular}{ccc}
\hline Perlakuan & $\begin{array}{c}\text { Rerata Total Tanin per gram } \\
\text { ekstrak (mg TAE) }\end{array}$ & $\begin{array}{c}\text { Rerata Total Tanin terekstraksi per } \\
\text { gram kulit manggis (mg TAE) }\end{array}$ \\
\hline P1 & $(67,10 \pm 2,35)^{\mathrm{a}}$ & $0,98 \pm 0,03^{\mathrm{b}}$ \\
P2 & $(62,93 \pm 11,95)^{\mathrm{a}}$ & $1,48 \pm 0,57^{\mathrm{b}}$ \\
P3 & $(19,13 \pm 2,47)^{\mathrm{b}}$ & $3,64 \pm 0,49^{\mathrm{a}}$ \\
P4 & $(17,26 \pm 4,69)^{\mathrm{b}}$ & $3,86 \pm 0,39^{\mathrm{a}}$ \\
\hline P1 = Ekstrak dalam bufer Na-asetat $0,05 \mathrm{M} \mathrm{pH} \mathrm{5,5}$ & \\
P2 = Ekstrak dalam bufer Na-asetat $0,05 \mathrm{M} \mathrm{pH} 5,5$ dan selulase & \\
P3 = Ekstrak dalam etanol 50\%-bufer Na- asetat $0,05 \mathrm{M}$ pH 5,5 & \\
P4 = Ekstrak dalam etanol 50\%-bufer Na-asetat $0,05 \mathrm{M}$ pH 5,5 dan selulase \\
ATE = Asam tanin ekuivalen \\
Harga rata-rata dengan notasi huruf yang sama, tidak berbeda secara nyata pada tingkat 5\% $(p \geq 0,05)$. Sedangkan harga rata-rata dengan \\
notasi huruf yang berbeda menunjukkan perbedaan secara nyata pada tingkat 5\% $(p<0,05)$ berdasarkan uji Duncan jarak berganda.
\end{tabular}

Tabel 2. menunjukkan bahwa secara signifikan $(p<0,05)$ terdapat peningkatan total tanin terekstraksi per gram kulit buah manggis pada penambahan etanol $50 \%$ dibandingkan tanpa etanol (Bandingkan P3 terhadap P1 dan P4 terhadap P2). Hal ini berhubungan dengan pelarut etanol yang digunakan untuk ekstraksi yang dapat mempengaruhi kandungan total tanin terekstraksi.

Kandungan total tanin dengan perlakuan tanpa dan menggunakan enzim tidak memberikan perbedaan hasil yang nyata pada $(p \geq 0,05)$. Penambahan enzim selulase pada proses ekstraksi dengan etanol ternyata tidak mengubah total tanin yang terekstraksi dari kulit buah manggis. Temuan ini berbeda dengan temuan Gomez-Garcia et al., (2012), yang menemukan bahwa penambahan enzim pektinase, selulase atau $\beta$-glukosidase mampu meningkatkan ekstraksi senyawa fenolik antioksidan dari limbah anggur.

\section{KESIMPULAN}

Dari hasil ekstraksi kulit buah manggis dapat disimpulkan: Kandungan total senyawa tanin ekstrak kulit buah manggis dengan pelarut etanol $50 \%$ dalam bufer Na-asetat $0,05 \mathrm{M}$ pH 5,5 dengan bantuan enzim selulase per gram kulit manggis adalah $3,86 \pm 0,39 \mathrm{mg}$ ATE. Nilai ini tidak berbeda nyata dari ekstraksi dalam ekatrak etanol $50 \%$ tanpa penambahan selulase $(p \geq 0,05)$.

\section{DAFTAR PUSTAKA}

Boyer, R. 1993. Modern Experimental Biochemistry. $3^{\text {rd }}$ edition. Benjamin Cummings, San Francisco.

Chomnawang, T.M., Surassmo, S.V., and Gritsanapan, W. 2005. Antimicrobial effects of Thai medicinal plants against acne-inducing bacteria. Journal of Ethnopharmacol. 101: ,330-333.

Gomez-Garcia, R., Martinez-Avila, G. C. G., and Aguilar, C. N. 2012. Enzyme-assisted extraction of antioxidative phenolics from grape (Vitisvinifera L.) residues.3 Biotech.2:297-300.

Ho, C. K., and Huang, C.. 2002. Garcinone E, a Xanthone Derivative, Has Potent Cytotoxic Effect Against Hepatocellular Carcinoma Cell Lines. Planta Med, 68, 975-979.

Jung, H. A., Su, B. N., Keller, W. J., Mehta, R. G., and Kinghorn, A. D. 2006. Antioxidant Xanthones from The Pericarp of Garcinia mangostana (Mangosteen). $J$ Agric. Food. Chem.54, 2077-2082.

Kumar, A., Baboota, S., Agarwal, S.P., Ali, J., and Ahuja, A. 2008. Treatment of acne with special emphasis on herbal remedies. 
Expert ReviewofDermatology. 3: 111122.

Pothitirat, W., Chomnawang, M. T., and Supabphol, R. 2010. Free radical scavenging and anti-acne activities of mangosteen fruit rind extracts prepared by different extraction methods. Pharmaceutical Biology; 48(2): 182-186.

Saxena, V., Mishra, G., Saxena, A., Kamlesh Kr., and Vishwakarma, K. Kr. 2013. A comparative study on quantitative estimation of tannins in Terminalia chebula, Terminalia belerica, Terminalia arjuna and Saracaindica using spectrophotometer. Asian Journal of Pharmaceutical and Clinical Research. 6: 148-149.

Weecharangsan, W., Opanasopit, P., Sukma, M., Ngawhirunpat, T., Sotanaphun, U., Siripong, P. 2006. Antioxidative and Neuroprotective Activities of Extracts from The Fruit Hull of Mangosteen (Garcinia mangostana Linn.). Med Princ Pract. 15,281-28.

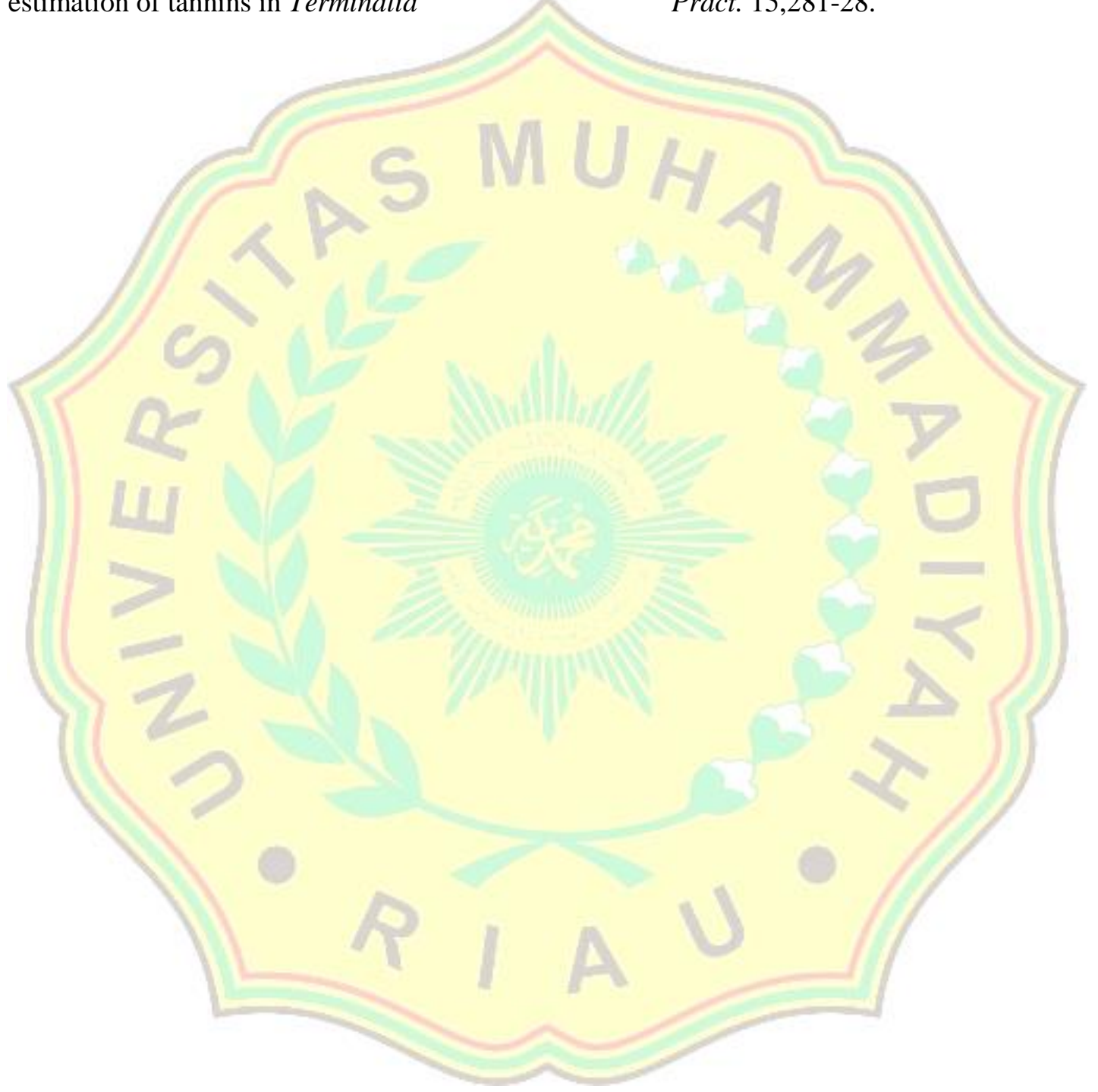

